\title{
Histopathological evaluation of chromoblastomycosis: A literature review
}

\author{
Avaliação histopatológica da cromoblastomicose: Uma revisão de literatura \\ Evaluación histopatológica de la cromoblastomicosis: Una revisión de literatura
}

Mateus Cardoso do Amaral ORCID: https://orcid.org/0000-0003-2735-9892 Federal University of the Parnaiba Delta, Brazil

E-mail: mateuscamaral@gmail.com

André dos Santos Carvalho ORCID: https://orcid.org/0000-0001-5259-6481 Federal University of the Parnaiba Delta, Brazil E-mail: fko.andre@gmail.com

Even Herlany Pereira Alves ORCID: https://orcid.org/0000-0001-7566-1282 Federal University of the Parnaiba Delta, Brazil

E-mail: even.herlany@gmail.com

Hélio Mateus Silva Nascimento ORCID: https://orcid.org/0000-0003-1551-8139 Federal University of the Parnaiba Delta, Brazil E-mail: heliomattheus2@gmail.com

Ayane Araújo Rodrigues

ORCID: https://orcid.org/0000-0001-7792-6993 Federal University of the Parnaiba Delta, Brazil

E-mail: ayanerodrigues2012@hotmail.com

Vinicius da Silva Caetano

ORCID: https://orcid.org/0000-0002-6310-8495 Federal University of the Parnaiba Delta, Brazil E-mail: vsvinicius3@gmail.com

Bruno Costa Silva

ORCID: https://orcid.org/0000-0002-8125-8884 Federal University of the Parnaiba Delta, Brazil

E-mail: brunocostama@gmail.com

Thayaná Ribeiro Silva Fernandes ORCID: https://orcid.org/0000-0002-6590-4620 Federal University of the Parnaiba Delta, Brazil

E-mail: thayana.fernandes@hotmail.com

Jacks Renan Neves Fernandes ORCID: https://orcid.org/0000-0001-7868-0673 Federal University of the Parnaiba Delta, Brazil E-mail: jacks.renan@ifpi.edu.br

Nathalia Thamires Duarte Sousa do Rêgo ORCID: https://orcid.org/0000-0002-0711-249X Federal University of the Parnaiba Delta, Brazil

E-mail: nathaliathamiresduarte@gmail.com

Arisvelton Fernandes de Paiva ORCID: https://orcid.org/0000-0003-0964-2344

Federal University of Piaui, Brazil E-mail: arisveltonpaiva@gmail.com

Clarissy Andrade Costa Medeiros ORCID: https://orcid.org/0000-0002-8695-511X Federal University of the Parnaiba Delta, Brazil

E-mail: clarissy.andrade.costa@outlook.com

Sijomara Maria Costa Freitas ORCID: https://orcid.org/0000-0003-3443-7334 Uninassau, Brazil E-mail: sijomaramaria@gmail.com

Maria Sarah de Macedo Machado ORCID: https://orcid.org/0000-0002-8714-6437 Federal University of the Parnaiba Delta, Brazil E-mail: msarahmmachado@gmail.com

Daniel Fernando Pereira Vasconcelos ORCID: https://orcid.org/0000-0002-3331-452X Federal University of the Parnaiba Delta, Brazil E-mail: prof.dr.daniel.vasconcelos@gmail.com 


\begin{abstract}
Chromoblastomycosis (CBM) is a cutaneous or subcutaneous mycoses. The trauma occurs when the fungus is installed and is more prevalent in individuals living in tropical and subtropical regions, with earliest descriptions dating back to 1920. The diagnosis of CBM is based on the incidence of cases in the endemic areas and is commonly reached through microbiological analyses to identify the etiologic agent in clinical samples. The process for the analysis of the collected samples allows one to visualise the muriform cells, which are brown, rounded structures having crossed chambers and that can be commonly called sclerotic bodies, characterising the positive diagnosis. The objective of this review was to verify the connection of the histopathological techniques to the diagnosis of CBM.
\end{abstract}

Keywords: Fungus; Chromoblastomycosis; Diagnosis; Histology; Histologic technique.

\title{
Resumo
}

A cromoblastomicose (CBM) é uma micose cutânea ou subcutânea. O trauma ocorre quando o fungo se instala e é mais prevalente em indivíduos que vivem em regiões tropicais e subtropicais, com as primeiras descrições datando de 1920. O diagnóstico de CBM é baseado na incidência de casos em áreas endêmicas e é comumente alcançado por meio microbiológico análises para identificar o agente etiológico em amostras clínicas. O processo de análise das amostras coletadas permite visualizar as células muriformes, que são estruturas castanhas, arredondadas, com câmaras cruzadas e que podem ser comumente chamadas de corpos escleróticos, caracterizando o diagnóstico positivo. O objetivo desta revisão foi verificar a conexão das técnicas histopatológicas com o diagnóstico de CBM.

Palavras-chave: Fungos; Cromoblastomicose; Diagnóstico; Histologia; Técnica histológica.

\section{Resumen}

La cromoblastomicosis (CBM) es una micosis cutánea o subcutánea. El trauma ocurre cuando el hongo se establece y es más prevalente en individuos que viven en regiones tropicales y subtropicales; las primeras descripciones datan de 1920. El diagnóstico de CBM se basa en la incidencia de casos en áreas endémicas y comúnmente se logra a través de medios microbiológicos. análisis para identificar el agente etiológico en muestras clínicas. El proceso de análisis de las muestras recolectadas permite visualizar las células muriformes, que son estructuras marrones, redondeadas, con cámaras cruzadas y que comúnmente pueden denominarse cuerpos escleróticos, caracterizando el diagnóstico positivo. El propósito de esta revisión fue verificar la conexión entre las técnicas histopatológicas y el diagnóstico de CBM.

Palabras clave: Hongos; Cromoblastomicosis; Diagnóstico; Histologia; Técnica histológica.

\section{Introduction}

Chromoblastomycosis (CBM) is a cutaneous or subcutaneous mycoses. The trauma occurs when the fungus installs and is more prevalent in individuals living in tropical and subtropical regions, especially in Madagascar, South Africa and Latin America (Venezuela, Brazil and Mexico). Its first descriptions date from 1920 (López Martínez \& Mendez Tovar, 2007; McGinnis, 1983; Queiroz-Telles et al., 2009; Queiroz-Telles et al., 2011). Fonseceae predosoi is the most common etiological agent, but other agents also cause the disease: Phialophora verrucosa, Cladophialophora carrionii, Fonsecaea compacta and Rhinocladiella aquaspersa (Ameen, 2009). Cellular modifications may offer greater chemical, biological and physical stress resistance. CBM has characteristic modifications in fungal cells and is specific to the parasitic form of the infecting fungus. These structures are known as sclerotic cells and characterise the virulence factor of the pathogen from CBM (Mendoza, Karuppayil, \& Szaniszlo, 1993; De Hoog et al., 2000; Da Silva et al., 2008; Badali et al., 2008). Regarding the clinical manifestations and diagnosis, after inoculation of the agent and after the incubation period, lesions appear on the inoculated site and the progression of CBM can start in single, isolated macular lesions and progress to reddish papules that gradually increase over the weeks and soon after reach the squamous stage. At the stages considered to be more serious, CBM may present other forms of lesions such as: polymorphic, papillomatous, nodular, cauliflower, verruciform, hyperkeratotic, scar, plaque or combinations, usually in the lower limbs; it does not present spontaneous cure. These polymorphic characteristics of the disease may cause different types of diagnosis, which may cause diagnostic imprecision (Queiroz-Telles et al., 2009; Queiroz-Telles et al., 2011; Bonifaz, Carrasco-Gerard \& Saul, 2010; Queiroz-Telles \& Santos, 2013). The diagnosis of CBM is based on the incidence of cases in the endemic areas and is commonly approached through microbiological analyses to identify the etiologic agent in clinical samples. Standard procedures are biopsies or skin scraping made at the site of the lesion, essentially in the darker areas of the lesion. The process for the analysis of the collected samples allows one to visualize the 
muriform cells, which are rounded brown structures having crossed chambers and that can be commonly called sclerotic bodies or fumagoid cells (Aldoory, 1983; Queiroz-Telles et al., 2009; Queiroz-Teles et al., 2011).

\section{Methodology}

This study proposed a systematic review with the objective of answering the following question: How are histopathological techniques linked to the diagnosis of patients with chromoblastomycosis? The bibliographic search occurred during the month of November, 2019, in the databases PUBMED and MEDLINE. The selected sample met criteria (Figure 1) as: identification, screening, eligibility and inclusion (Moher, Liberati, Tetzlaff \& Galvão, 2014).

Figure 1. Flow diagram for identification, screening, eligibility and analysis of studies included in this systematic review.
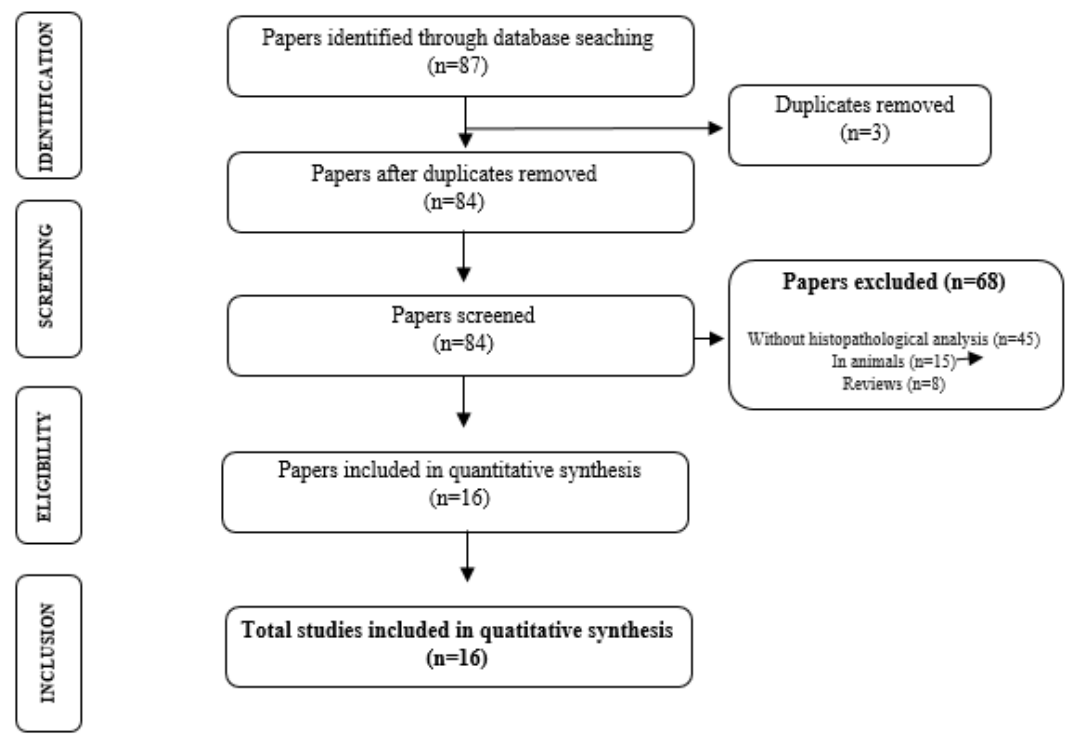

Source: The authors.

In the identification and screening, the criteria adopted for inclusion were: be available in the electronic address in full and be published in English; the publications should meet the time interval of 11 years, 2008 to 2019. Thus, we excluded other publications that did not fit in the screening criteria or were repeated in the databases. The selected descriptors are contained in the list of descriptors of the MeSH (Medical Subject Headings), which are: fungus, chromoblastomycosis, diagnosis, histology and histologic technique.

For the eligibility of publications, all pre-selected articles were accurately analysed through the reading of the titles and abstracts and methodology applied so that it was possible to confirm whether it was really connected to the guiding question of this study and would meet the inclusion and established. After this step, the inclusion phase of the articles was carried out

\section{Results and Discussion}

Sixteen articles analysed in this study were taken from the PubMed (13) and Medline (3) databases, all published in international English language journals. Histopathological techniques were used in all thirteen articles selected to perform the precise diagnosis of the disease> Histological sections are stained mainly with hematoxylin and eosin and fifteen of the articles (94\%) analysed effectively identified the presence of murine cells or sclerotic bodies. Only one article (6\%) could not be 
diagnosed as positive, since the specific histological findings associated with CBM were not present in the samples analysed in the study.

In order to confirm the diagnosis of CBM, experimental protocols often use histopathological analysis techniques to identify CBM specific structures, such as "murine cells" in injured tissue, which is usually achieved with a potassium hydroxide (KOH) clarification method (Mittal et al., 2014; Hay, 2019) associated with hematoxylin and eosin staining (He et al., 2019 ;Bhattacharjee \& Chatterjee, 2019), allowing a more complete analysis of the tissue, such as the presence of inflammation, a recurrent condition in this type of mycosis.

According to Gajjar et al. (2011), obtaining accurate diagnosis of chromoblastomycosis depends mainly on the identification of brown sclerotic bodies or muriform cells, although it should be used with fontanelles such as Fontana Masson and silver methenamine nitrate from Gomori. The process of transepithelial migration of sclerotic bodies and their autoinoculation or even lymphatic dissemination could explain the lesions in the body.

According to Pradeepkumar et al. (2011), histopathological findings typical of chromoblastomycosis are epitheliomatous hyperplasia, microabscesses, chronic granulomatous infiltrates with multinucleated giant cells, epithelioid cells, histiocytes and lymphocytes and presence of muriform cells. In the articles analysed, the occurrence of several common findings to CBM were verified, such as pseudoepitheliomatous hyperplasia as the most recurrent finding, which was present in $44 \%$ of the studies, multinucleated giant cells (37\%), inflammatory cells (31\%), and lower incidence microabscesses $(12 \%)$ and glanulomas $(6 \%)$ were observed. These findings associated with the presence of murine cells in the tissue under analysis characterize the diagnosis of the disease as shown in Table 1, other clinical manifestations such as nodules, squamous plaques or warts may recur, patient information as to where they live or visited also endemic in the process diagnostic hypothesis (Queiroz-Telles et al., 2009; Queiroz-Telles et al., 2011).

Table 1. Characteristics of the studies and histological application.

\begin{tabular}{|c|c|c|c|c|}
\hline Authors & Title & Coloring & Diagnosis & Histopathological findings \\
\hline $\begin{array}{l}\text { Chavan et } \\
\text { al. }{ }^{17}\end{array}$ & $\begin{array}{l}\text { Unstained' and 'de stained' } \\
\text { sections in the diagnosis of } \\
\text { chromoblastomycosis: a clinico- } \\
\text { pathological study. }\end{array}$ & $\begin{array}{l}\text { Silver nitrate } \\
\text { Gomori } \\
\text { methanamine } \\
\text { and } \\
\text { Hemotoxylin } \\
\text { and Eosin }\end{array}$ & Positive & $\begin{array}{l}\text { Sclerotic bodies; } \\
\text { Giant cell; } \\
\text { Micro abscess; } \\
\text { Pseudoepitheliomatous } \\
\text { hyperplasia; } \\
\text { Unusual hyphae; }\end{array}$ \\
\hline $\begin{array}{l}\text { Abdullah et } \\
\text { al. }{ }^{18}\end{array}$ & $\begin{array}{l}\text { Successful treatment of } \\
\text { chromoblastomycosis of } 10 \text {-year } \\
\text { duration due to Fonsecaea nubica }\end{array}$ & $\begin{array}{l}\text { Hemotoxylin } \\
\text { and Eosin }\end{array}$ & Positive & $\begin{array}{l}\text { Sclerotic bodies; } \\
\text { Multinucleated giant cells; }\end{array}$ \\
\hline $\begin{array}{l}\text { Azevedo et } \\
\text { al. }{ }^{19}\end{array}$ & $\begin{array}{l}\text { Squamous cell carcinoma derived } \\
\text { from chronic } \\
\text { chromoblastomycosis in Brazil }\end{array}$ & $\begin{array}{l}\text { Hemotoxylin } \\
\text { and Eosin }\end{array}$ & Positive & $\begin{array}{l}\text { Muriform cells; } \\
\text { Atypical number of mitoses; } \\
\text { Numerous neutrophils }\end{array}$ \\
\hline Badali et al. ${ }^{20}$ & $\begin{array}{l}\text { Rhinocladiella aquaspersa, proven } \\
\text { agent of verrucous skin infection } \\
\text { and a novel type of } \\
\text { chromoblastomycosis }\end{array}$ & $\begin{array}{l}\text { Hemotoxylin } \\
\text { and Eosin }\end{array}$ & Positive & Muriform cells; \\
\hline $\begin{array}{l}\text { Camara- } \\
\text { Lemarroy et } \\
\text { al. }^{21}\end{array}$ & $\begin{array}{l}\text { Case of chromoblastomycosis } \\
\text { with pulmonary involvement }\end{array}$ & $\begin{array}{l}\text { Hemotoxylin } \\
\text { and Eosin }\end{array}$ & Positive & Muriform cells; \\
\hline Gajjar et al. ${ }^{15}$ & Severe pigmented keratitis caused & $\begin{array}{l}\text { Hemotoxylin } \\
\text { and Eosin }\end{array}$ & Positive & Sclerotic bodies; \\
\hline
\end{tabular}


Research, Society and Development, v. 10, n. 6, e47410616027, 2021

(CC BY 4.0) | ISSN 2525-3409 | DOI: http://dx.doi.org/10.33448/rsd-v10i6.16027

\begin{tabular}{|c|c|c|c|c|}
\hline & by Cladorrhinum bulbillosum & & & \\
\hline Jamil et al. $^{22}$ & $\begin{array}{l}\text { Invasive squamous cell carcinoma } \\
\text { arising } \\
\text { chromoblastomycosis }\end{array}$ & $\begin{array}{l}\text { Hemotoxylin } \\
\text { and Eosin }\end{array}$ & Positive & $\begin{array}{l}\text { Sclerotic bodies; } \\
\text { Pseudoepitheliomatous } \\
\text { hyperplasia; } \\
\text { Multiple neutrophilic abscesses; } \\
\text { Multinucleated giant cells; }\end{array}$ \\
\hline Kim et al. ${ }^{23}$ & $\begin{array}{l}\text { Chromoblastomycosis Caused by } \\
\text { Fonsecaea pedrosoi. }\end{array}$ & $\begin{array}{l}\text { Hemotoxylin } \\
\text { and Eosin }\end{array}$ & Positive & $\begin{array}{l}\text { Muriform cells; } \\
\text { Pseudoepitheliomatous } \\
\text { hyperplasia; } \\
\text { Chronic glanulomatous } \\
\text { inflammation }\end{array}$ \\
\hline Lyon et al. ${ }^{24}$ & $\begin{array}{lr}\text { Photodynamic } & \text { Antifungal } \\
\text { Therapy } & \text { Against } \\
\text { Chromoblastomycosis } & \end{array}$ & $\begin{array}{l}\text { It was not } \\
\text { described }\end{array}$ & Positive & $\begin{array}{l}\text { Muriform cells; } \\
\text { Gingant cells; } \\
\text { Microabcesses. }\end{array}$ \\
\hline $\begin{array}{l}\text { Pradeepkum } \\
\text { ar et al. }{ }^{16}\end{array}$ & $\begin{array}{l}\text { Chromoblastomycosis caused by } \\
\text { Cladophialophora carrionii in a } \\
\text { child from India }\end{array}$ & $\begin{array}{l}\text { It was not } \\
\text { described }\end{array}$ & Inaccurate & $\begin{array}{l}\text { No characteristics common to the } \\
\text { disease were found }\end{array}$ \\
\hline Purim et al. ${ }^{25}$ & $\begin{array}{l}\text { Chromoblastomycosis: Tissue } \\
\text { modifications during itraconazole } \\
\text { treatment }\end{array}$ & $\begin{array}{l}\text { Hemotoxylin } \\
\text { and Eosin }\end{array}$ & Positive & $\begin{array}{l}\text { Muriform cells; Hyperkeratosis; } \\
\text { Pseudoepitheliomatous } \\
\text { hyperplasia; Inflammatory dermal } \\
\text { infiltration; }\end{array}$ \\
\hline Zhu et al. ${ }^{26}$ & $\begin{array}{l}\text { Cutaneous Chromoblastomycosis } \\
\text { Caused by Veronaea botryosa in a } \\
\text { Patient with Pemphigus Vulgaris } \\
\text { and Review of Published Reports }\end{array}$ & $\begin{array}{l}\text { Hemotoxilin } \\
\text { and Eosin; } \\
\text { Periodic Acid- } \\
\text { Schiff }\end{array}$ & Positive & $\begin{array}{l}\text { Muriform cells; } \\
\text { Giant cells; } \\
\text { Hapht. }\end{array}$ \\
\hline $\begin{array}{l}\text { De Azevedo } \\
\text { et al. } .^{27}\end{array}$ & $\begin{array}{l}\text { Fonsecaea pugnacius, a novel } \\
\text { agent of disseminated } \\
\text { chromoblastomycosis }\end{array}$ & $\begin{array}{l}\text { It was not } \\
\text { described }\end{array}$ & Positive & Muriform cells; \\
\hline $\begin{array}{l}\text { Weedon et } \\
\text { al. }{ }^{28}\end{array}$ & $\begin{array}{l}\text { Chromoblastomycosis } \\
\text { Australia: An } \\
\text { perspective }\end{array}$ & $\begin{array}{l}\text { Hemotoxylin } \\
\text { and Eosin }\end{array}$ & Positive & $\begin{array}{l}\text { Muriform cells } \\
\text { Severe pseudoepitheliomatous } \\
\text { hyperplasia; } \\
\text { Tuberculoid glanulomas; } \\
\text { Inflammatory cells; }\end{array}$ \\
\hline Le et al. ${ }^{29}$ & $\begin{array}{l}\text { Case Report: A Case of } \\
\text { Chromoblastomycosis Caused by } \\
\text { Fonsecaea pedrosoi in Vietnam }\end{array}$ & $\begin{array}{l}\text { Hemotoxylin } \\
\text { and Eosin }\end{array}$ & Positive & $\begin{array}{l}\text { Muriform cells } \\
\text { Pseudoepitheliomatous } \\
\text { hyperplasia; } \\
\text { Granulomatous inflammatory } \\
\text { infiltrat; }\end{array}$ \\
\hline Zhang et al. ${ }^{30}$ & $\begin{array}{l}\text { A Case of Chromoblastomycosis } \\
\text { Caused by Fonsecaea Pedrosoi } \\
\text { and Investigation of the } \\
\text { Pathogenic Fungi } \\
\text { Received: }\end{array}$ & $\begin{array}{l}\text { Hemotoxylin } \\
\text { and Eosin }\end{array}$ & Positive & $\begin{array}{l}\text { Muriform cells } \\
\text { Intraepithelial hyperplasia; } \\
\text { Infiltration by neutrophils; } \\
\text { Plasma cells; } \\
\text { Lymphocytes; } \\
\text { Multinucleated giant cells; }\end{array}$ \\
\hline
\end{tabular}

Source: The Authors.

As observed in the studies (Table 1), routine histology using Hematoxylin and eosin (HE) has been the most widely used method in the diagnosis of a wide spectrum of diseases (Freudiger et al., 2012): hematoxylin stains the purple nucleus and eosin stains the pink cytoplasm (Stefanovic \& Marija, 2015) but both the preparation and the analysis of more complex structures require a longer time, which prevents the use of conventional histopathology (Giacomelli et al., 2016). In light of 
that, some studies have showed promising alternatives in terms of cost and real-time application, such as the use of cyanine $\mathrm{R}$ eriochrome, a synthetic anionic dye, which has selective nuclear staining rather similar to conventional hematoxylin and with a lower cost (Giacomelli et al., 2016; Stefanovic, 2015).

New histopathological techniques have been approached in studies all over the world. One of them is the immunofluorescence histopathology analysis that allows the visualization of several biomarkers simultaneously (Lahiani \& Eldadi, 2018; Burlingame et al., 2018), besides the visualization of fresh tissues without the need to process or cut them. Such methods provide faster diagnosis of diseases and have the same efficacy as more common dyes such as hematoxylin and eosin (Elfer et al., 2016).

Therefore, the use of histopathological techniques to diagnose and verify characteristic findings of CBM are indispensable in the help to diagnose the disease.

\section{Final Considerations}

From the analysis of the studies, it is clear that the use of histopathological techniques for the diagnosis of CBM has been effective to confirm the disease. Hematoxylin and eosin staining was present in $94 \%$ of the analysed studies and favoured the identification of the main histological findings common to CBM, such as Muriform Cells, Pseudoepitheliomatous Hyperplasia and Giant Cells. CBM is a complex disease and accurate diagnosis is required to perform appropriate treatment as quickly as possible. Recent studies have indicated new alternatives that use faster systems for histopathological analysis, incorporating these techniques in the diagnosis of CBM would probably make it faster, favouring medical interventions.

It is suggested that more in vivo studies may be carried out in the future, with incorporation of histological techniques to visualize not only the strains, but also to know the pathophysiological profile of this disease, so that this knowledge can be incorporated into current diagnostic methods.

\section{References}

Abdullah, E., Idris, A., \& Saparon., A. (2017). Papr reduction using scs-slm technique in stfbc mimo-ofdm. ARPN Journal of Engineering and Applied Sciences 12(10):3218-3221.

Al-Doory, Y. (1983). Chromomycosis. In: Di Salvo, A. F. Occupational mycoses. Philadelphia: Lea \& Febiger, 95-121.

Ameen, M. (2009). Chromoblastomycosis: clinical presentation and management. Clin Exp Dermatol; 34:849 - 854. https://doi.org/10.1111/j.13652230.2009.03415.x.

Azevedo, C. M. P. S., Marques, S. G., \& Santos, D. W. C. L. (2015). Squamous cell carcinoma derived from chronic chromoblastomycosis in Brazil. Clinical Infectious Diseases, 60(10):1500-1504. https://doi.org/10.1093/cid/civ104.

Badali, H., Bonifaz, A., \& Barrn-Tapia, T. (2010). Rhinocladiella aquaspersa, proven agent of verrucous skin infection and a novel type of chromoblastomycosis. Medical Mycology, 48(5):696-703. https://doi/org/10.3109/13693780903471073.

Badali, H., et al. (2008). Biodiversity of the genus Cladophialophora. Stud Mycol, 61(1):175-91. https://doi.org/10.3114/sim.2008.61.18.

Bhattacharjee, R., Narang, T., \& Chatterjee, D. (2019). Cutaneous Chromoblastomycosis: A Prototypal Case. Journal of cutaneous medicine and surgery, 23(1):98-98. https://doi.org/10.1177/1203475418789029.

Bonifaz, A., Carrasco-Gerard, E., \& Saul, A. (2010). Chromoblastomycosis: clinical and mycologic experience of 51 cases. Mycoses, 44:1-7. https://doi.org/ 10.1046/j.1439-0507.2001.00613. x.

Burlingame, E. A., et al. (2018). SHIFT: speedy histopathological-to-immunofluorescent translation of whole slide images using conditional generative adversarial networks. In: Medical Imaging 2018: Digital Pathology. International Society for Optics and Photonics, 1058105. https://doi.org/10.1117/12.2293249.

Camara-Lemarroy, C. R., Soto-Garcia, A. J., \& Preciado-Yepez, C. I. (2013). Case of chromoblastomycosis with pulmonary involvement. Journal of Dermatology, 2013; 40(9):746-748. https://doi.org/10.1111/1346-8138.12216.

Chavan, S. S., Kulkarni., M. H., \& Makannavar, J. H. (2010). "Unstained" and "de stained" sections in the diagnosis of chromoblastomycosis: a clinicopathological study. Indian journal of pathology \& microbiology, 53(4):666-671. https://doi.org/10.4103/0377-4929.72021. 
Da Silva., et al. (2008). Development of natural culture media for rapid induction of Fonsecaea pedrosoi sclerotic cells in vitro. J Clin Microbiol, 46(11):38393841. https://doi.org/10.1128/JCM.00482-08.

De Azevedo., C. M., Gomes, R. R., \& Vicente, V. A. (2015). Fonsecaea pugnacius, a novel agent of disseminated chromoblastomycosis. Journal of Clinical Microbiology, 53(8):2674-2685. https://doi.org/10.1128/JCM.00637-15.

De Hoog, G. S., et al. (2000). Black fungi: clinical and pathogenic approaches. Med Mycol, ;38:243-50.

Elfer, K. N., et al. (2016). DRAQ5 and eosin ('D\&E') as an analog to hematoxylin and eosin for rapid fluorescence histology of fresh tissues. PLoS One, 11(10): e0165530. https://doi.org/10.1371/journal.pone.0165530.

Freudiger, C. W., et al. (2012). Multicolored stain-free histopathology with coherent Raman imaging. Laboratory investigation, 92(10):1492. https://doi.org/10.1038/labinvest.2012.109.

Gajjar, D. U., Pal, A. K., \& Santos, J. M. (2011). Severe pigmented keratitis caused by Cladorrhinum bulbillosum. Indian J Med Microbiol, 29(4):434-437. https://doi.org/10.4103/0255-0857.90191. PMID: 22120812.

Galvão, T. F., \& Pereira, M. G. (2014). Revisões sistemáticas da literatura: passos para sua elaboração. Epidemiologia e Serviços de Saúde, 23(1):183-184. https://doi.org/10.5123/S1679-49742014000100018.

Giacomelli, M. G., et al. (2016).Virtual hematoxylin and eosin transillumination microscopy using epi-fluorescence imaging. PLoS One, 11(8):e0159337. https://doi.org/10.1371/journal.pone.0159337.

Hay, R. (2019). The diagnosis of fungal neglected tropical diseases (fungal NTDs) and the role of investigation and laboratory tests: An expert consensus report. Tropical medicine and infectious disease, 4(4):122. https://doi.org/10.3390/tropicalmed4040122.

He, L., et al. (2018). Successful treatment of chromoblastomycosis of 10-year duration due to Fonsecaea nubica. Mycoses, 61(4):231-236. https://doi.org/10.1111/myc.12732.

Jaleel, A., et al. (2017). Mycetoma-like chromoblastomycosis: a diagnostic dilemma. International journal of dermatology, 56(5):563-566. https://doi.org/10.1111/ijd.13499.

Jamil, A., Lee, Y. Y., \& Thevarajah, S. (2012). Invasive squamous cell carcinoma arising from chromoblastomycosis. Medical Mycology, 50(1):99-102. https://doi.org/10.3109/13693786.2011.571295.

Jayasree, P., et al. (2019). Dermoscopic features in nodular chromoblastomycosis. International journal of dermatology, 58(5):107-109. https://doi.org/10.1111/ijd.14344.

Kim, D. M., Hwang, S. M., \& Suh, M. K. (2011). Chromoblastomycosis Caused by Fonsecaea pedrosoi. Annals of dermatology, 23(3):369-74. https://doi.org/10.5021/ad.2011.23.3.369

Lahiani, A. K., \& Eldad, G. R. O. (2018). Enabling Histopathological Annotations on Immunofluorescent Images through Virtualization of Hematoxylin and Eosin. J Pathol Inform. https://doi.org/10.4103/jpi.jpi_61_17.

Le, Ta., et al. (2019). Case Report: A Case of Chromoblastomycosis Caused by Fonsecaea pedrosoi in Vietnam, Mycopathologia, 184(1):115-119. 10.1007/s11046-018-0284-3.

López-Martínez., \& Méndez-Tovar, L. J. (2007). Chromoblastomycosis. Clin Dermatol, 25:188-94. https://doi.org/10.1128/CMR.00032-16.

Lyon, J. P., et al. (2011). Photodynamic Antifungal Therapy Against Chromoblastomycosis. Mycopathologia, 172( 4):293-297. https://doi.org/10.1007/s11046-011-9434-6.

Mcginnis, M. R. (1983). Chromoblastomycosis and phaeohyphomycosis: new concepts, diagnosis, and mycology. J Am Acad Dermatol,8:1-16. https://doi.org/10.1016/s0190-9622(83)70001-0.

Mendoza, L., Karuppayil, S. M., \& Szaniszlo, P. J. (1993). Calcium regulates in vitro dimorphism in chromoblastomycotic fungi. Mycoses, 36(5-6):157-64. 10.1111/j.1439-0507.1993.tb00744.x.

Mittal, A., et al. (2014). Chromoblastomycosis from a non-endemic area and response to itraconazole. Indian journal of dermatology, 59(6):606. https://doi.org/10.4103/0019-5154.143537.

Moher, D., Liberati, A., \& Tetzlaff, J. (2009). Guidelines and Guidance Preferred Reporting Items for Systematic Reviews and Meta-Analyses: The PRISMA Statement. PLoS Med, 6: e1000097. https://doi.org/10.1186/2046-4053-4-1.

Pradeepkumar, N. S., \& Joseph, N. M. (2011). Chromoblastomycosis caused by Cladophialophora carrionii in a child from India. Journal of Infection in Developing Countries, 5 (7):556-560. https://doi.org/10.3855/jidc.1392.

Purim, K. S. M., Peretti., M. C., \& Neto, J. F. (2017). Chromoblastomycosis: Tissue modifications during itraconazole treatment. Anais Brasileiros de Dermatologia 2017; 92(4):478-483. https://doi.org/10.1590/abd1806-4841.20175466.

Queiroz-Telles, F., et al. (2009). Chromoblastomycosis: an overview of clinical manifestations, diagnosis and treatment. Med Mycol, 47:3-15. https://doi.org/10.1080/13693780802538001.

Queiroz-Telles, F., \& Santos, D. W. (2013). Challenges in the therapy of chromoblastomycosis. Mycopathologia, 175:477-88. https://doi.org/10.1007/s11046013-9648-x. 
Research, Society and Development, v. 10, n. 6, e47410616027, 2021

(CC BY 4.0) | ISSN 2525-3409 | DOI: http://dx.doi.org/10.33448/rsd-v10i6.16027

Queiroz-Telles, F., et al. (2011). Mycoses of implantation in Latin America: an overview of epidemiology, clinical manifestations, diagnosis and treatment. Med Mycol, 49:225-36. https://doi.org/10.3109/13693786.2010.539631.

Stefanović, D. (2015). Use of eriochrome cyanine R for routine histology and histopathology: an improved dichromatic staining procedure. Biotechnic \& Histochemistry, 90(6):470-474. https://doi.org/10.3109/10520295.2015.1058420.

Stefanović, D. S., \& Marija, L. D. (2015). Use of eriochrome cyanine R in routine histology and histopathology: is it time to say goodbye to hematoxylin? Biotechnic \& histochemistry, 90(6):461-469. https://doi.org/10.3109/10520295.2015.1057765.

Weedon, D., Deurse, M., \& Allison, S. (2013). Chromoblastomycosis in Australia: An historical perspective. Pathology, 45(5):489-491. https://doi.org/10.1097/PAT.0b013e32836326a1.

Zhang, R., et al. (2019). A Case of Chromoblastomycosis Caused by Fonsecaea Pedrosoi and Investigation of the Pathogenic Fungi, Mycopathologia, 184(2):349-352. https://doi.org/10.1007/s11046-019-0319-4

Zhu, C. Y., Yang, Y. P., \& Sheng, P. (2015). Cutaneous Chromoblastomycosis Caused by Veronaea botryosa in a Patient with Pemphigus Vulgaris and Review of Published Reports. Mycopathologia, 180(1-2):123-129. https://doi.org/10.1007/s11046-015-9887-0. 